\title{
PRODUKTIFKAH HUMAN CAPITAL INVESTMENT OLEH PEMERINTAH DAERAH PROVINSI DALAM ERA DESENTRALISASI?
}

\author{
Bambang Suprayitno, Tejo Nurseto, \& Supriyanto \\ Universitas Negeri Yogyakarta, Indonesia \\ Email: bambang_s@uny.ac.id
}

\begin{abstract}
Abstrak: Produktifkah Human Capital Investment oleh Pemerintah Daerah Provinsi dalam Era Desentralisasi? Efektivitas pengeluaran pemerintah khususnya human capital investment dalam meningkatkan produktivitas tenaga kerja juga tergantung dari pemilihan pemda dalam menentukan jenis pengeluaran tersebut. Tujuan dari penelitian ini untuk mengetahui pengaruh pengeluaran belanja pemerintah secara umum maupun secara fungsional terhadap produktivitas tenaga kerja melalui pendekatan kuantitatif dengan metode ekonometrika. Penelitian ini menggunakan data sekunder dari ringkasan APBD pemda seluruh Indonesia yang disediakan oleh Kemenkeu Dirjen Perimbangan Keuangan Daerah RI. Data yang digunakan adalah data tahun 2012 dengan unit analisis perekonomian level provinsi seluruh Indonesia. Pengeluaran pemerintah provinsi secara total tidak mempengaruhi produktivitas tenaga kerja regional. Pengeluaran pemerintah daerah provinsi dalam fungsi human capital investment tidak efektif meningkatkan produktivitas tenaga kerja meski demikian pengeluaran pemerintah dalam bidang fasilitas umum dan perumahan mempengaruhi secara positif produktivitas tenaga kerja regionalnya.
\end{abstract}

Kata Kunci: pemerintah daerah, human capital investment, produktivitas tenaga kerja, desentralisasi fiskal, pengeluaran pemerintah

\begin{abstract}
Is The Human Capital Investment of Provincial Governments Productive in Decentralization Era? The effectiveness of government spending, especially investment in human capital, increases labor productivity also depends on how the local government determines the type of expenditure. The purpose of this study is to determine the effect of government spending in general and functionally to labor productivity. The approach used in this study is a quantitative approach, econometric method. This study uses secondary data from local government budgets across Indonesia summary provided by the Indonesian Ministry of Finance Directorate General of Regional Financial Balance. The data used is the provincial-level economic analysis units throughout Indonesia in 2012. This research shows that provincial government spending in human capital investment does not effectively increase labor productivity. Total provincial government spending does not affect the regional labor productivity. Government spending in the areas of public facilities and housing positively influence regional labor productivity.
\end{abstract}

Keywords: local government, human capital investment, labor productivity, fiscal decentralization, public spending

\section{PENDAHULUAN}

Seiring dengan berjalannya desentralisasi, banyak terjadi mengalirnya aliran uang ke daerah di mana dana yang semula dikelola oleh pemerintah pusat (pemerintah) dialihkan ke daerah. Dengan pola seperti ini maka pemerintah daerah diharapkan mampu menangkap aspirasi dari rakyat sebagai principal-nya. Dengan semakin dekatnya objek dan subjek pembangunan 
dengan kuasa pengguna anggaran yaitu pemerintah daerah (pemda) maka jalannya pembangunan benar-benar dapat dioptimalkan untuk kepentingan rakyat banyak.

Otonomi daerah mempunyai banyak dimensi dan secara umum dibagi atas 3 hal yaitu desentralisasi administrasi, desentralisasi politik, dan desentralisasi fiskal. Dari ketiganya ini yang seringkali dilupakan adalah sisi kesiapan dari sisi fiskal. Pola desentralisasi fiskal ini bersifat tricky pengaruhnya terhadap kesejahteraan masyarakat di daerah tergantung dari kesiapan kapasitas pengelolaan uang pemda.

Pendapat para ahli mengenai desentralisasi sendiri mempunyai perbedaan. Hal ini dikarenakan adanya ketidaksamaan dari dimensi yang diajukan. Treisman (2002) mempertimbangkan desentralisasi untuk berbagai sisi yaitu struktur, keputusan, sumber daya, pemilihan, dan institusional. Kaufman et.al. (2006) mempertimbangkan enam dimensi tata kelola yaitu akuntabilitas dan kebebasan berbicara, stabilitas politik dan rendahnya pelanggaran, efektivitas pemerintah, kualitas peraturan, serta tata aturan dan pengawasan terhadap korupsi. Sedangkan La Porta et al (1998) mengklasifikasikan variabel kinerja pemerintah ke dalam lima kelompok yaitu intervensi terhadap sektor swasta, efisiensi sektor publik, penyediaan barang publik, ukuran (besarnya) pemerintah, dan kebebasan politik. Agrawal dan Ribot (2002) mengemukakan dimensi desentralisasi sebagaimana yang dikemukakan oleh Menor yaitu administrasi, fiskal, dan demokrasi. Binswanger menyatakan bahwa desentralisasi mempunyai dimensi politik, fiskal, dan administrasi.

Lebih lanjut Agrawal dan Ribot mengemukakan bahwa untuk menjalankan desentralisasi adalah tergantung dari pelaku, kekuasaan, dan akuntabilitasnya. Tanpa memahami kekuasaan dari berbagai pelaku, domain yang dikerjakan dalam melaksanakan kekuasaan, dan kepada siapa harus bertanggung jawab maka mustahil untuk mempelajari pengembangan untuk mengartikan arti dari desentralisasi ditempatkan. Dalam pandangan konsepnya, lebih lanjut Agrawal dan Ribot mengemukakan bahwa domain politik dan administrasi dari desentralisasi dicirikan dengan perpaduan antara ketiga dimensi tersebut.

Trend dan tantangan baru dalam mengelola pemerintahan dalam globalisasi adalah menjalankan pembangunan yang sifatnya berkelanjutan. Menurut Gupta et al (2002), pembangunan berkelanjutan terdiri dari tiga pilar. Tiga pilar tersebut antara lain adalah pembangunan ekonomi, pembangunan social, dan perlindungan lingkungan. Esensi dari pilar adalah untuk mempertahankan dan meningkatkan kapasitas dan kemampuan generasi mendatang serta memenuhi kebutuhan generasi sekarang. Untuk mencapai tugas yang bersifat multi-dimensi, human capital harus dibudidayakan strategis dan diposisikan untuk pelestarian baik saat ini dan pertumbuhan ekonomi masa depan dan pembangunan. Lyakurwa (2007) menyatakan bahwa manusia mempunyai tiga esensi pilihan untuk hidup yang lebih berkualitas yaitu mempunyai hidup yang lama dan sehat, memperoleh pengetahuan, dan 
mendapatkan akses terhadap sumber daya agar bisa memperoleh standard hidup yang layak. Jika berbagai esensi ini tidak terpenuhi maka kesempatan untuk hidup lebih baik tidak akan tercapai termasuk pertumbuhan dan pembangunan ekonomi.

Dari berbagai esensi yang dikemukakan tersebut maka jelas sekali bahwa untuk mendapatkan kualitas hidup yang lebih baik maka investasi human capital sangatlah diperlukan yaitu investasi di bidang pendidikan dan kesehatan. Dengan investasi pendidikan, produktivitas akan meningkat melalui peningkatan teknologi dan peningkatan pengetahuan sebagai basis pertumbuhan ekonomi. Kesehatan juga seiring dengan pendidikan, tingkat kesehatan yang baik akan mendukung peningkatan pendidikan yang lebih baik dengan indikasi nutrisi, mobilitas, kejadian sakit, dan tingginya penduduk (Lyakurwa, 2007).

Pada masa sekarang ini paradigma pembangunan manusia harus meliputi (UNDP, 2010) prinsip produktivitas, keadilan, kesinambungan, dan pemberdayaan. Prinsip ini digunakan untuk pendekatan pembangunan manusia (human capital) dengan meningkatkan kesehatan, pendidikan, dan ketrampilan.

Kyriacou \& Sagalés mengemukakan bahwa desentralisasi bisa meningkatkan kualitas pemerintahan dengan berbagai cara. Kualitas pemerintahan bisa meningkat dengan berbagai jalan yang antara lain pemerintah lokal dapat meningkatkan kepuasan rakyat dalam menerima pelayanan publik dikarenakan mendapatkan informasi yang lebih tepat, penduduk lokal bisa melakukan kontrol serta juga bisa melakukan reward dan punishment-nya sekaligus mengarahkan jalannya pemerintahan lokal yang lebih baik, fiscal didesentralisasikan dengan menetapkan kewenangan yang sifatnya fleksibel dan penuh kompetisi maka diharapkan pemda mampu menyediakan barang publik dengan efisien atau lebih responsive terhadap permintaan dan dengan biaya rendah serta juga menciptakan tingkat korupsi yang lebih rendah di daerah. Dengan jalan seperti ini, baik pemerintah daerah maupun rakyat mendapatkan sisi positifnya.

Dengan adanya desentralisasi, muncul adanya prinsip mekanisme akuntabilitas. Akuntabilitas itu sendiri dibentuk dari adanya kompetisi eksternal dengan pemerintahan yang lain dan juga adanya tekanan dalam pemda itu sendiri yang berkaitan dengan demokrasi lokalnya (Bardhan dan Mookherjee, 2005). Namun tidak bisa dipungkiri, secara umum, adanya kekurangan dalam pertanggungjawaban pemerintahan yang muncul pada umumnya di negara transisi dan berkembang. Hal ini terjadi karena adanya malfungsi dari demokrasi lokal, yang berhubungan dengan asimetri pengetahuan, kekayaan, status sosial, dan pola partisipasi politik.

Di negara yang masih berkembang, kondisi di daerah berbeda dengan di pusat khususnya untuk kapasitas sumber daya manusianya. Dengan kondisi ini maka administrasi di daerah lemah, penegakan rule of the game kurang baik. Karena kondisi ini maka akuntabilitas pelaksana elit di daerah menjadi lemah juga. Ketika kewenangan yang diberikan besar baik dari sisi fungsi maupun finansialnya namun kapasitas administrasi terbatas dan akuntabilitas rendah maka tentunya 
mempunyai risiko penyelewengan yang besar dan juga rentan terjadinya korupsi.

Suprayitno (2011) menunjukkan bahwa semakin besar desentralisasi fiskal yang diterima oleh pemerintah daerah semakin meningkatkan korupsi yang ada di daerah. Ini bisa terjadi mengingat proses desentralisasi di Indonesia sejak tahun 2001 dijalankan secara tiba-tiba seiring dengan adanya reformasi yang menghasilkan perubahan termasuk dalam struktur pemerintahan sehingga dihasilkan UU No.22 tentang Pemerintah Daerah Tahun 1999 dan diperbarui dengan UU No. 32 Tahun 2004. Proses yang tiba-tiba ini tidak diiringi dengan kapasitas tata kelola yang lebih baik daripada sebelumnya.

Dalam era desentralisasi fiskal, Rp518.9T dari Rp1657.7T anggaran belanja dalam RAPBN 2013 disalurkan secara langsung kepada pemda melalui dana perimbangan (Kemenkeu, 2012). Namun lebih dari itu pemerintah juga menyalurkan sekitar $30 \%$ uang APBN melalui kementerian dan lembaga yang dibelanjakan di daerah. Dengan demikian, ada sekitar $65 \%$ uang yang ada di APBN dijalankan atau dihabiskan di daerah. Dengan skema seperti ini maka baik atau buruknya jalannya pembangunan di Indonesia tergantung dari baik atau buruknya kualitas pemda dalam menjalankan pembangunan.

Hanya saja yang mesti disayangkan adalah implementasi dari pelaksanaan APBD yang seringkali banyak dihabiskan untuk belanja yang tidak ditujukan untuk kesejahteraan rakyat. Misalkan saja, tidak sedikit dari pemda yang menghabiskan APBDnya untuk belanja pegawai. Secara nasional rata-rata belanja pegawai terhadap total belanja adalah $42 \%$ bahkan ada beberapa daerah yang mempunyai belanja pegawai sebesar lebih dari $70 \%$ dari total belanja seperti halnya Aceh Barat, Langsa, dan Ciamis, dll (Kemenkeu, 2012).

Pengeluaran yang bersifat investasi diharapkan lebih diutamakan dan diperhatikan mengingat pengeluaran pemerintah jenis ini menciptakan multiplier yang lebih besar daripada sekedar bersifat konsumsi. Dengan investasi pengeluaran yang dilakukan tidak hanya sekedar mengalir dan hilang begitu saja melainkan akan menjadi faktor produksi yang nantinya dapat meningkatkan tingkat output di masa depan.

Stansel (2009) mengemukakan bahwa pengeluaran pemerintah dalam arti luas tidak begitu penting dalam hubungannya dengan pertumbuhan ekonomi. Namun ketika pengeluaran ini dirinci menjadi komponen yang lebih spesifik yaitu pengeluaran investasi maka menunjukkan bahwa semakin besar investasi pemerintah dilakukan maka semakin tinggi pertumbuhan yang didapatkannya. Di sisi lain, sebagaimana yang diharapkan. Investasi pemerintah ini juga efektif menurunkan tingkat pengangguran pada daerah tersebut.

Temuan yang serupa dengan yang dikemukakan oleh Denaux (2007) yang menyatakan bahwa pengeluaran pemerintah lokal pada pendidikan yang lebih tinggi signifikan mempengaruhi pertumbuhan ekonomi daerah tersebut. Namun untuk pengeluaran pada tingkat yang lebih rendah yaitu sekolah tidak mempunyai pengaruh terhadap pertumbuhan ekonomi. Penelitian yang dilakukan pada level yang lebih makro oleh Oluwatobi \& Ogunrinola (2011) di Negeria juga menunjukkan bahwa 
pengeluaran pemerintah dalam pendidikan dan kesehatan meningkatkan pertumbuhan ekonomi. Temuan pada level yang lebih luas, Dao (2012) juga menunjukkan bahwa pengeluaran pemerintah dalam investasi human capital ini sangatlah penting. Penelitian ini menunjukkan bahwa pertumbuhan ekonomi negara bergantung pada tingkat pengeluaran pemerintah di bidang pendidikan, kesehatan, selain investasi lainnya.

Dari permasalahan pentingnya belanja pemerintah dalam investasi human capital ini maka penting untuk dilakukan penelitian. Dalam era desentralisasi fiskal, peran dari pemerintah daerah provinsi dan kab/kota sangatlah penting dalam mewujudkan tujuan pembangunan. Namun tidak terlepas sisi negatif yang didapatkan pengeluaran pemerintah yang dihasilkan bisa disalaharahkan dalam pengeluaran yang tidak banyak manfaatnya terhadap peningkatan kesejahteraan rakyat.

Dari berbagai uraian yang telah disampaikan sebelumnya maka diperlukan penelitian dalam level pemerintah daerah dalam hal ini pemerintah daerah provinsi untuk mengetahui seberapa jauh pengaruh pengeluaran pemerintah khususnya sesuai fungsi yaitu investasi human capital dalam pendidikan dan kesehatan dalam mempengaruhi produktivitas tenaga kerja.Tujuan dari penelitian ini adalah untuk mengetahui pengaruh pengeluaran belanja pemerintah daerah dalam fungsi pendidikan dan kesehatan (human capital investment) terhadap produktivitas tenaga kerja, pengaruh pengeluaran belanja pemerintah daerah terhadap produktivitas tenaga kerja, dan efektivitas pengeluaran pemerintah daerah dalam belanja secara umum dibandingkan dengan pengeluaran pemerintah dalam human capital investment terhadap produktivitas tenaga kerja.

Sebagaimana pada umumnya fungsi produksi mengacu pada fungsi teoretis CobbDouglas production function (Yeoh dan Stansel, 2013):

$$
Y=f(K, L)
$$

Marginal produktivitasnya masing-masing maka fungsi tersebut bisa dikembangkan sebagai berikut, di mana $\alpha$ dan $\beta$ adalah masing-masing elastisitas output terhadap perubahan $\mathrm{K}$ dan $\mathrm{L}$ terhadap:

$$
Y=A \cdot K^{\alpha} L^{\beta}
$$

Dengan mengasumsikan produksi yang dilakukan mempunyai pola constant return to scale, dan persamaan di atas dibagi dengan L maka:

$$
\frac{Y}{L}=A .\left(\frac{K}{L}\right)^{\alpha}
$$

Dengan melogkan kedua sisinya maka bisa diperoleh:

$$
\operatorname{Ln}\left(\frac{Y}{L}\right)=\operatorname{Ln}(A)+\alpha \operatorname{Ln}\left(\frac{K}{L}\right)
$$

A sendiri adalah total factor productivity (TFP) di mana TFP ini bisa diperoleh dari pengeluaran pemerintah dalam berbagai sarana layanan public seperti fasilitas air, jalan, listrik, kesehatan, pendidikan, dan lainlain, sehingga:

$$
\begin{aligned}
& \operatorname{Ln}(A)=A+\gamma P U B L I C \\
& \operatorname{Ln}\left(\frac{Y}{L}\right)=A+\gamma P U B L I C+\alpha \operatorname{Ln}\left(\frac{K}{L}\right)
\end{aligned}
$$

Di mana A adalah time effect dan PUBLIC adalah pengeluaran publik. Model produktivitas tenaga kerja inilah yang 
dijadikan model acuan dalam mengestimasi hubungan antar variabel yang diteliti.

\section{METODE}

Pendekatan yang digunakan dalam penelitian ini adalah pendekatan kuantitatif dengan metode ekonometrika. Data yang akan diolah dalam penelitian ini adalah data sekunder dari ringkasan APBD pemda seluruh Indonesia yang disediakan oleh Kemenkeu Dirjen Perimbangan Keuangan Daerah RI dengan unit analisis perekonomian level provinsi dari 33 provinsi seluruh Indonesia pada tahun 2012. Objek penelitian ini adalah PDRB, populasi, serta berbagai variabel dari APBD seperti halnya belanja daerah, belanja pegawai, serta berbagai belanja yang berdasarkan fungsi yang sesuai dengan investasi human capital seperti halnya belanja dalam fungsi pendidikan dan kesehatan.

Model yang dijadikan rujukan dalam penelitian ini adalah model yang digunakan oleh Yeoh dan Stansel (2013) dalam meneliti pengaruh pengeluaran pemerintah terhadap produktivitas tenaga kerja yang ada di kotakota besar di US. Model yang dipakai tersebut dimodifikasi sebagaimana berikut uraian ini.

Dengan mengubah nama dan dimodifikasi persamaan tersebut maka didapatkan persamaan berikut:

$$
\begin{aligned}
& \operatorname{LnVALUE}=A+\gamma i P U B L I C i+\alpha \operatorname{Ln}\left(\frac{K}{L}\right)+ \\
& \beta 1 L n P O P+\beta 2 \operatorname{LnLAND}
\end{aligned}
$$

Di mana:

VALUE: produktivitas tenaga kerja, produktivitas tenaga kerja yang bisa diperoleh dari PDRB per tenaga kerja di masing-masing provinsi,
PUBLICi: terdiri dari berbagai pengeluaran, hanya saja yang kita gunakan adalah tiga macam pengeluaran yaitu pengeluaran pendidikan (Geduc), pengeluaran kesehatan (GHeal), dan pengeluaran pelayanan/rumah dan fasilitas umum (GFac),

$\mathrm{K} / \mathrm{L}$ : stok modal per kapita tenaga kerja. Untuk proxynya digunakan perubahan modal bruto pada PDRB penggunaan, sehingga $\ln (\mathrm{K} / \mathrm{L})$ diproxy dengan CapbInL.

POP: populasi pada provinsi tersebut.

LAND: luas wilayah pada provinsi tersebut.

Sedangkan untuk mengetahui pengaruh pengeluaran pemerintah secara total maka variabel PUBLICi akan diganti dengan pengeluaran pemerintah secara total.

\section{HASIL DAN PEMBAHASAN}

Deskripsi data yang akan disajikan dari hasil penelitian ini adalah untuk memberikan gambaran secara umum mengenai penyebaran data yang diperoleh. Unit analisis dalam penelitian ini adalah provinsi dengan demikian data yang digunakan adalah data keuangan daerah di tingkat provinsi. Sumber data sekunder yang digunakan penelitian adalah dari BPS berbagai terbitan dan data keuangan dari Dirjen Perimbangan Keuangan Daerah.

Nilai terendah produktivitas tenaga kerja menurut harga berlaku tahun 2012 adalah Rp12.74 juta yang merupakan PDRB per kapita provinsi Maluku Utara. Sedangkan nilai tertinggi adalah Rp235.4juta yang merupakan PDRB provinsi Kalimantan Utara. Untuk variabel pengeluaran belanja pemerintah daerah tahun 2012 menunjukkan bahwa nilai terendah adalah 
Tabel 1. Statistik Deskriptif

\begin{tabular}{lrrrrr}
\hline & \multicolumn{1}{c}{ Mean } & \multicolumn{1}{c}{ Median } & \multicolumn{1}{c}{ Maximum } & \multicolumn{1}{c}{ Minimum } & \multicolumn{1}{c}{ Std. Dev. } \\
\hline POP (jiwa) & $7,264,055$ & $3,641,600$ & $43,224,600$ & 785,000 & $10,453,302$ \\
VALUE (Rp juta) & 52.20 & 35.44 & 235.40 & 12.74 & 51.06 \\
CAP (Rp juta) & $42,041,094.00$ & $18,195,528.00$ & $340,000,000.00$ & $560,797.20$ & $67,219,315.00$ \\
GEDUC (Rp juta) & $550,400.40$ & $219,000.30$ & $10,120,366.00$ & $32,921.21$ & $1,732,454.00$ \\
GHEAL(Rp juta) & $430,452.30$ & $228,645.00$ & $3,344,062.00$ & $30,156.20$ & $635,249.80$ \\
GFAC (Rp juta) & $771,520.00$ & $442,487.40$ & $6,192,056.00$ & $123,362.80$ & $1,121,309.00$ \\
GTOT (Rp juta) & $5,137,511.00$ & $2,874,685.00$ & $33,240,019.00$ & $668,470.00$ & $6,267,898.00$ \\
LAND Km ${ }^{2}$ & $60,316.61$ & $42,224.65$ & $365,466.00$ & 740.29 & $73,585.55$ \\
\hline
\end{tabular}

Sumber: Data diolah dari berbagai sumber

Rp668,470 juta yang merupakan pengeluaran belanja pemerintah daerah Provinsi Lampung. Sedangkan nilai tertinggi adalah Rp33,240,019 juta yang merupakan pengeluaran belanja pemerintah daerah provinsi DKI Jakarta.

Untuk variabel pengeluaran belanja pemerintah daerah dalam fungsi pendidikan diperoleh nilai terendah sebesar Rp32,921.21 juta yang merupakan pengeluaran belanja pemerintah dalam fungsi pendidikan daerah Maluku Utara. Sedangkan nilai tertinggi sebesar Rp10,120,366 juta yang merupakan pengeluaran belanja pemerintah daerah dalam fungsi pendidikan provinsi DKI Jakarta. Untuk variabel pengeluaran belanja pemerintah daerah dalam fungsi kesehatan diperoleh nilai terendah pengeluaran belanja pemerintah daerah dalam fungsi kesehatan tahun 2012 sebesar Rp30,156.2 juta yang merupakan pengeluaran belanja pemerintah dalam fungsi kesehatan daerah provinsi Gorontalo. Sedangkan nilai tertinggi diperoleh nilai sebesar Rp3,344,062 juta yang merupakan pengeluaran belanja pemerintah daerah dalam fungsi kesehatan provinsi DKI Jakarta. Untuk variabel pengeluaran belanja pemerintah daerah dalam fungsi pelayanan rumah/fasilitas umum diperoleh nilai terendah pengeluaran belanja pemerintah daerah dalam pelayanan rumah/fasilitas umum tahun 2012 sebesar Rp123,362.8 juta yang merupakan pengeluaran belanja pemerintah dalam fungsi pelayanan rumah/fasilitas umum daerah provinsi Gorontalo. Sedangkan nilai tertinggi diperoleh nilai sebesar Rp6,192,056 juta yang merupakan pengeluaran belanja pemerintah daerah dalam fungsi pelayanan rumah/fasilitas umum provinsi DKI Jakarta.

Jumlah penduduk diperoleh nilai terendah sebesar 785000 jiwa yang merupakan jumlah penduduk daerah provinsi Papua Barat. Sedangkan nilai tertinggi diperoleh nilai sebesar 43,224,600 jiwa yang merupakan jumlah penduduk provinsi Jawa Barat. Luas wilayah yang terkecil adalah sebesar $740.29 \mathrm{~km}^{2}$ yang merupakan luas wilayah provinsi DKI Jakarta Sedangkan provinsi terluas adalah sebesar $365,466 \mathrm{~km}^{2}$ yang merupakan luas wilayah provinsi Papua.

Dari tipologi provinsi gambar 1, scatter tersebut menunjukkan kecenderungan hubungan semakin tinggi HDI (sumbu $X$ ) yang 


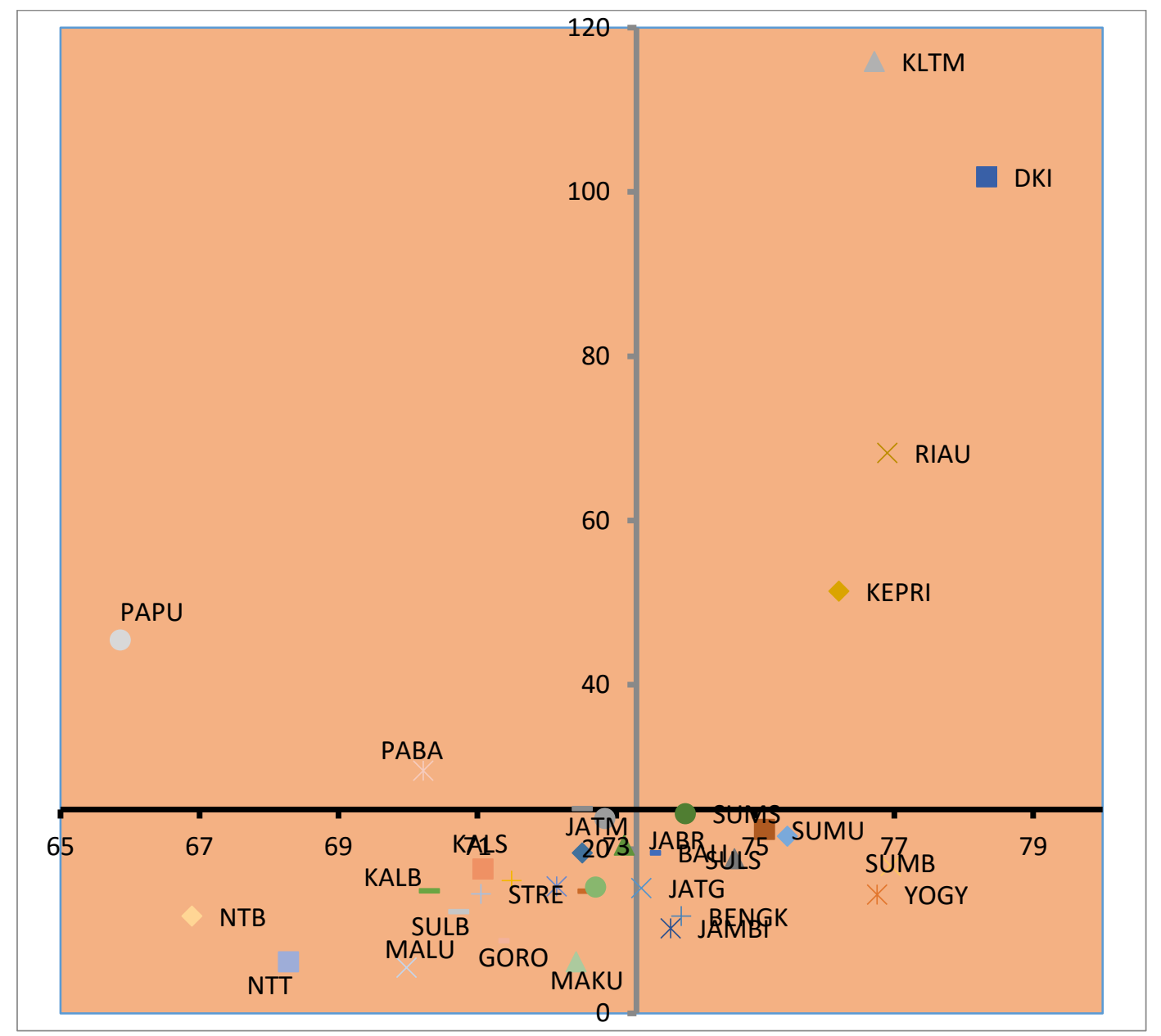

Gambar 1. Tipologi Provinsi Berdasar HDI (Sumbu X) dan PDRB per kapita (Sumbu Y dalam Rpjuta) Tahun 2012

dipunyai oleh daerah tersebut semakin tinggi PDRB per kapita penduduk (sumbu Y) di daerah tersebut. Ini menunjukkan bahwa semakin berkualitas SDM yang dimiliki maka semakin meningkatkan pencapaian ekonomi daerahnya.

Gambar memperlihatkan bahwa daerah yang mempunyai HDI di atas rata-rata di Indonesia mempunyai PDRB per kapita yang kebanyakan masih di bawah rata-rata yaitu Rp24.82 juta per tahun. Hanya empat provinsi yang mempunyai kondisi yang terbaik yaitu Kaltim, DKI jaya, Riau, dan Kepri yang mempunyai kondisi HDI yang tinggi sekaligus PDRB per kapita yang tinggi pula.
Dari tipologi yang ada tersebut, kawasan Indonesia Timur mendominasi dalam klasifikasi yang terendah. Daerah tersebut mempunyai kualitas SDM yang rendah sekaligus mempunyai kemajuan ekonomi yang rendah pula dibanding daerah-daerah lainnya. Ini menunjukkan kondisi yang sangat timpang antara Indonesia Timur dan Indonesia Barat. Yang sangat memprihatinkan adalah Papua dan Pabar yang mempunyai nilai PDRB per kapita yang tinggi namun kualitas SDMnya rendah sebagaimana yang ditunjukkan oleh rendahnya HDI.

Sedangkan dalam tipologi provinsi gambar 2, scatter tersebut menunjukkan 


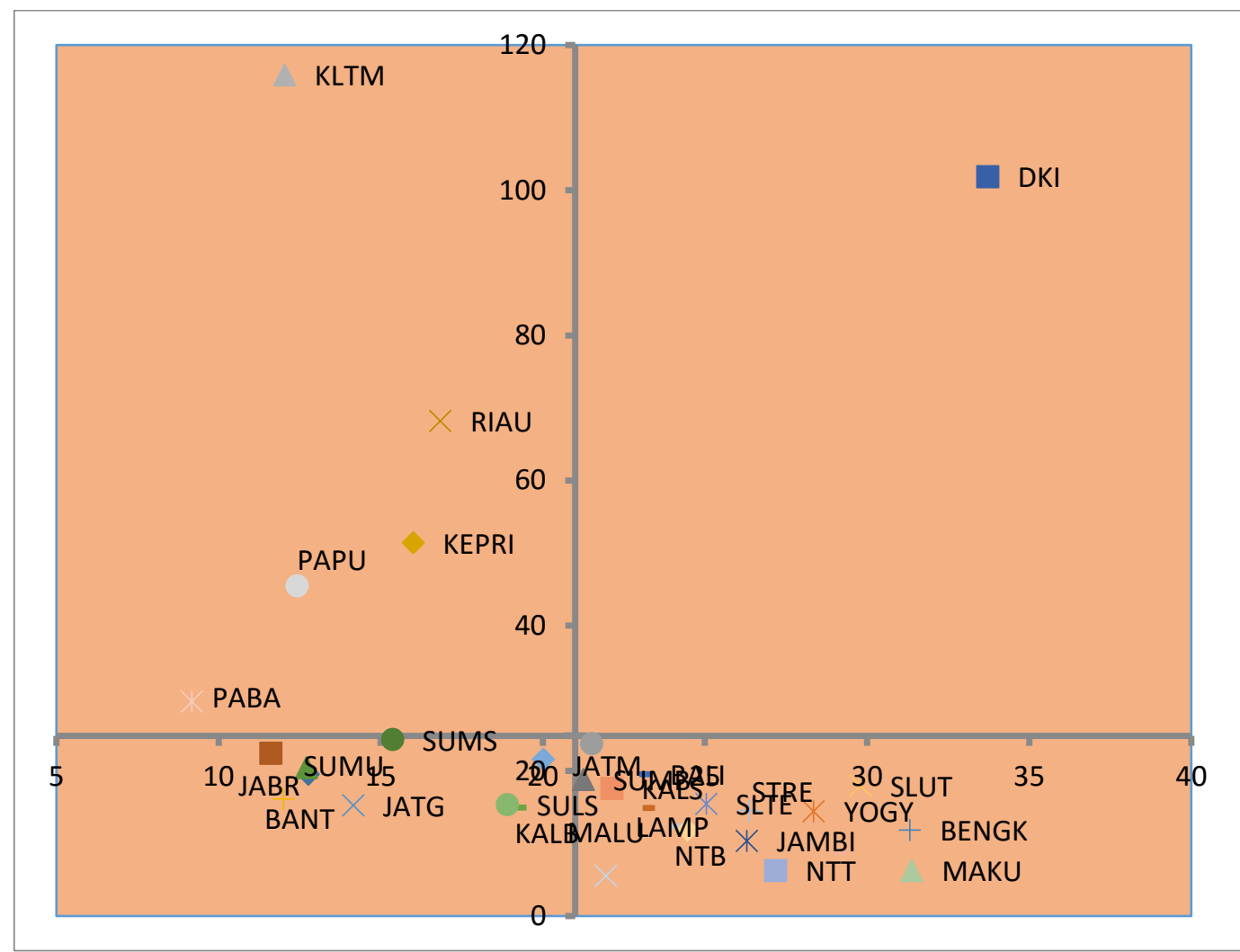

Gambar 2. Tipologi Provinsi Berdasar Rasio Belanja Pegawai Terhadap Total Belanja (Sumbu X dalam \%) dan PDRB per kapita (Sumbu Y dalam Rpjuta) Tahun 2012

kecenderungan hubungan semakin tinggi rasio belanja pegawai (sumbu $\mathrm{X}$ ) yang dilakukan pemda daerah tersebut semakin menurunkan PDRB per kapita penduduk (sumbu Y) di daerah tersebut. Ini menunjukkan bahwa semakin besar rasio belanja pegawai yang menunjukkan tidak efisiennya kinerja pemda yang bersangkutan semakin memperburuk pencapaian ekonomi daerahnya. Ini menunjukkan bahwa semakian boros belanja pegawai yang dilakukan semakin terabaikan kondisi ekonomi rakyatnya karena belanja yang dilakukan tidak dipakai untuk peningkatan modal daerah tersebut.

Tipologi tersebut juga bercerita bahwa hanya DKI yang mempunyai rasio belanja yang besar sekaligus mempunyai pencapaian ekonomi yang besar juga. Ini terjadi karena
DKI adalah pusat pemerintahan dan ekonomi sehingga sedikit banyak imbas ekonominya banyak karena kedua hal tersebut sehingga meski kinerja pemerintahannya kurang baik maka perekonomiannya tetap bagus.

Dari tipologi yang ada tersebut, kawasan Indonesia Timur mendominasi dalam klasifikasi di mana rasio belanja tinggi secara relatif namun PDRB per kapitanya rendah. Daerah tersebut mempunyai tingkat efisiensi pemda yang rendah sekaligus kemajuan ekonomi yang rendah pula dibanding daerah-daerah lainnya. Hal ini juga menunjukkan kondisi yang sangat timpang antara Indonesia Timur dan Indonesia Barat baik dalam hal ekonomi maupun pengelolaan keuangan daerahnya.

Dari tipologi provinsi gambar 3, scatter menunjukkan kecenderungan hubungan 


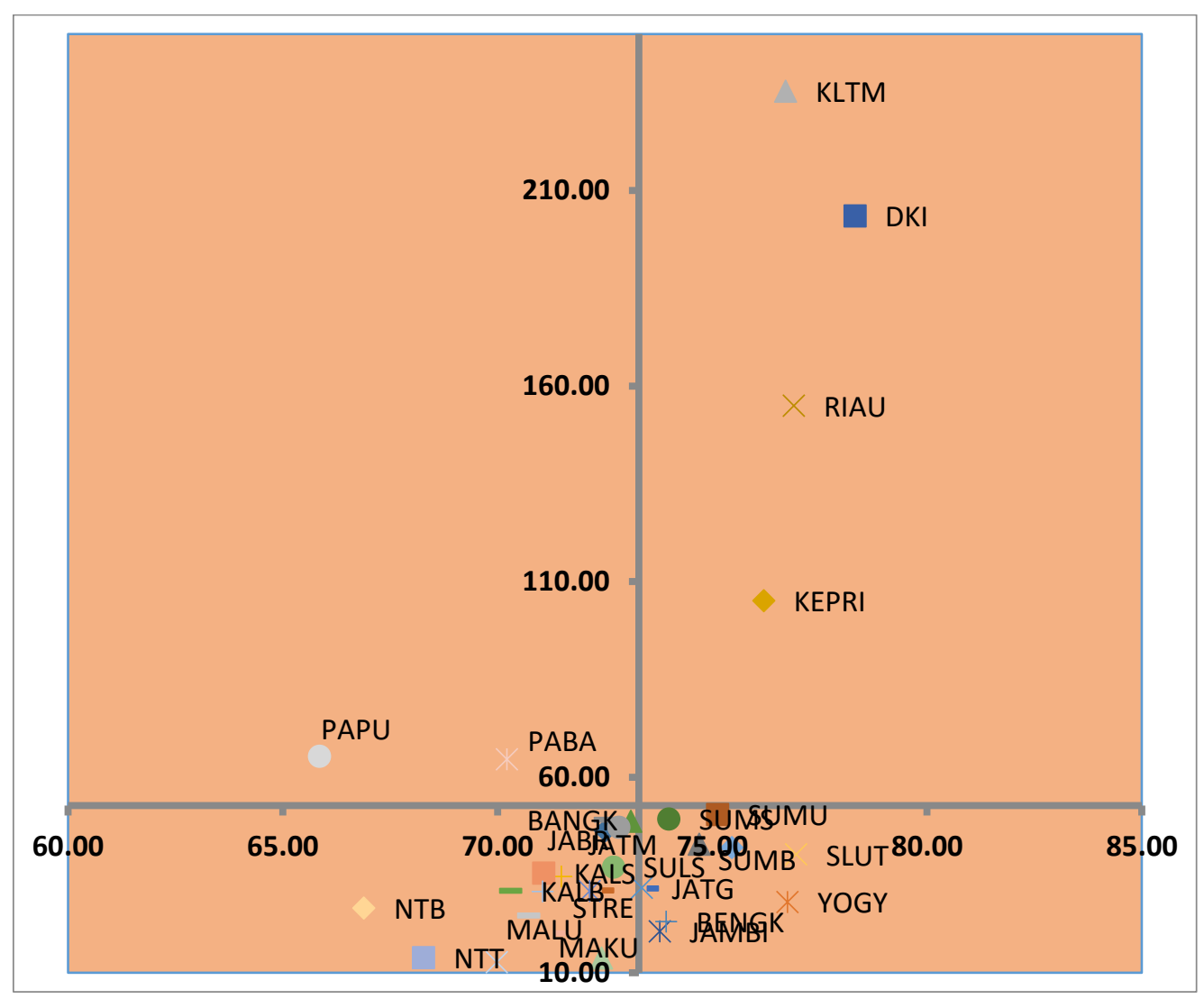

Gambar 3. Tipologi Provinsi Berdasar HDI (Sumbu X) dan Produktivitas Tenaga Kerja (Sumbu Y dalam Rpjuta) Tahun 2012

semakin tinggi HDI (sumbu $X$ ) yang dipunyai oleh daerah tersebut semakin tinggi produktivitas tenaga kerja (sumbu Y)di daerah tersebut. Ini menunjukkan bahwa semakin berkualitas SDM yang dimiliki maka semakin meningkatkan produktivitasnya tenaga kerjanya.

Hanya empat provinsi yang mempunyai kondisi yang terbaik, SDM yang bagus dan produktivitas tenaga kerja yang tinggi. Keempat provinsi tersebut antara lain Kaltim, DKI Jaya, Riau, dan Kepri.

Dari tipologi yang ada tersebut, kawasan Indonesia timur mendominasi dalam klasifikasi yang terendah. Daerah tersebut mempunyai kualitas SDM yang rendah sekaligus mempunyai produktivitas tenaga kerja yang rendah pula dibanding daerahdaerah lainnya. Untuk kasus Papua dan Pabar mempunyai sumber daya manusia yang rendah namun mempunyai produktivitas yang tinggi. Ini bisa terjadi mengingat besarnya SDA yang ada di Pulau Papua namun mempunyai jumlah penduduk yang sangat kecil dibandingkan daerah lain. Ini menunjukkan kondisi yang sangat timpang antara Indonesia Timur dan Indonesia Barat.

Dari tipologi provinsi gambar 4, scatter tersebut menunjukkan kecenderungan hubungan semakin tinggi Capital Expenditur_Capex (sumbu $X$ ) atau rasio belanja modal terhadap total belanja oleh daerah tersebut semakin tinggi produktivitas tenaga kerja (sumbu Y) di daerah tersebut. Ini menunjukkan bahwa semakin besar belanja modal yang dilakukan maka semakin meningkatkan produktivitasnya tenaga kerjanya. 


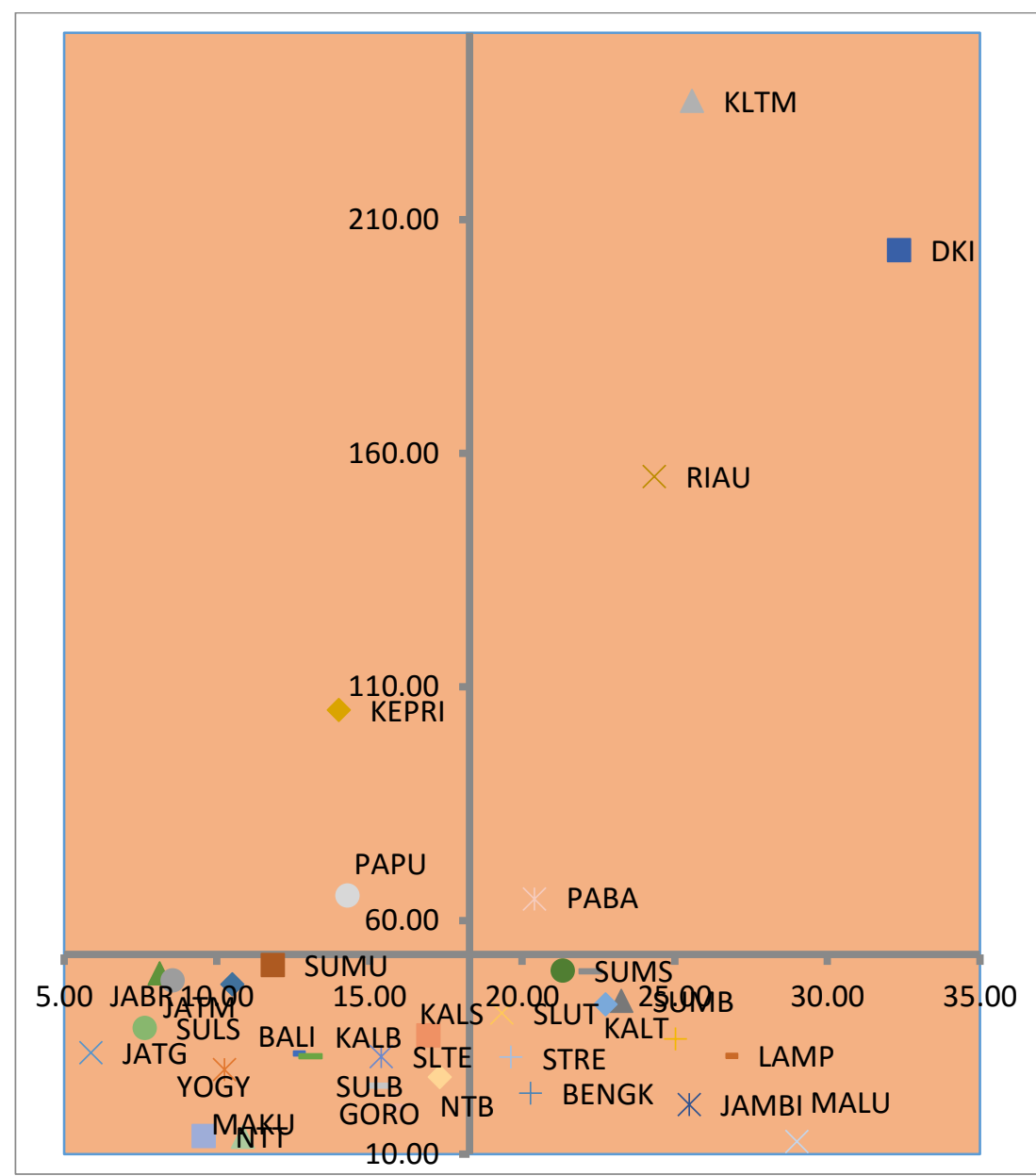

Gambar 4. Tipologi Provinsi Berdasar Rasio Capital Expe_Capex (Sumbu X dalam \%) dan Produktivitas Tenaga Kerja (Sumbu Y dalam Rpjuta)Tahun 2012

Secara tipologi, hanya empat provinsi yang mempunyai kondisi yang terbaik, Capex yang besar dan produktivitas tenaga kerja yang tinggi. Keempat provinsi tersebut antara lain Kaltim, DKI Jaya, Riau, dan Paba.

Dari tipologi tersebut, kawasan Indonesia timur mendominasi dalam klasifikasi yang terendah. Daerah tersebut mempunyai SDM yang rendah sekaligus mempunyai produktivitas tenaga kerja yang rendah pula dibanding daerah lainnya. Ini menunjukkan kondisi yang sangat timpang antara Indonesia Timur dan Indonesia Barat. Untuk kasus Papua dan Kepri mempunyai Capex rendah namun produktivitasnya tinggi. Ini terjadi karena Papua dan Kepri memiliki SDA yang besar namun jumlah penduduknya sangat kecil dibandingkan daerah lain.

Tabel 2. Hasil Estimasi Pengeluaran Pemerintah Menurut Fungsi

\begin{tabular}{l|c|c}
\hline \multicolumn{3}{c}{ Dependent Variabel: LOG(VALUE) } \\
\hline \multicolumn{1}{c}{ Variable } & Coefficient & \multicolumn{1}{c}{ Prob. } \\
\hline C & $7.651296^{* * *}$ & 0.001 \\
GEDUC & $-5.18 \mathrm{E}-07^{* * *}$ & 0.0047 \\
GHEAL & $-5.60 \mathrm{E}-07$ & 0.1013 \\
GFAC & $8.52 \mathrm{E}-07^{* * *}$ & 0.0002 \\
LOG(KLB) & $1.38 \mathrm{E}-08^{* * *}$ & 0.0007 \\
LOG(POP) & $-0.33994^{* *}$ & 0.0122 \\
LOG(LAND) & 0.04656 & 0.5689 \\
\hline R-squared $=0.698685$ \\
Adjusted R-squared $=0.629151$ \\
F-statistic = 10.04809, \\
Prob(F-statistic) $=0$ \\
\hline
\end{tabular}


Tabel 3. Hasil Estimasi Pengeluaran Pemerintah Secara Total

\begin{tabular}{l|r|r}
\hline \multicolumn{2}{c}{ Dependent Variabel: LOG(VALUE) } \\
\hline \multicolumn{1}{c}{ Variable } & \multicolumn{1}{c}{ Coefficient } & \multicolumn{1}{c}{ Prob. } \\
\hline C & $4.562442^{* *}$ & 0.0141 \\
GTOT & $2.69 \mathrm{E}-08$ & 0.582 \\
LOG(KLB) & $6.89 \mathrm{E}-09$ & 0.183 \\
LOG(POP) & $-0.21774^{*}$ & 0.0827 \\
LOG(LAND) & $0.192002^{* *}$ & 0.0401 \\
\hline
\end{tabular}

R-squared $=0.481098$

Adjusted R-squared $=0.40697$

F-statistic $=6.490032$

Prob(F-statistic) $=0$

\section{Estimasi Model dan Uji Diagnosis}

Sebagaimana dilakukan regresi linear berganda dengan persamaan yang telah diuraikan pada bab 3 yaitu persamaan (7) maka diperoleh hasil estimasi seperti pada Tabel 2. Sedangkan hasil estimasi model dengan menggunakan pengeluaran total pemerintah daerah provinsi (Gtot) dapat dilihat pada Tabel 3.

Sebelum diinterpretasikan parameter yang didapatkan maka terlebih dahulu diuji diagnosis yaitu apakah hasil estimasi tersebut melanggar asumsi klasik atau tidak. Jika melanggar asumsi klasik maka

Tabel 4. Uji Diagnostik Model Human Capital

\begin{tabular}{|c|c|c|c|c|c|}
\hline Asumsi & Uji & $\mathrm{Ho}$ & Hasil & Indikator Uji & Keterangan \\
\hline Normalitas & JB test & $\begin{array}{l}\text { Residual } \\
\text { Normal }\end{array}$ & OK & $\begin{array}{l}\mathrm{JB}=1.260053 \\
\text { Prob }=0,532578\end{array}$ & \\
\hline $\begin{array}{l}\text { Spesifikasi } \\
\text { Model }\end{array}$ & $\begin{array}{l}\text { Ramsey Reset } \\
\text { Test }\end{array}$ & $\begin{array}{l}\text { Spesifikasi } \\
\text { Baik }\end{array}$ & Baik & $\begin{array}{l}\text { F-statistic }=0.04848 \\
\text { Prob }=0.8275\end{array}$ & \\
\hline $\begin{array}{l}\text { Homo- } \\
\text { skedastisitas }\end{array}$ & $\begin{array}{l}\text { White } \\
\text { Heterokedasticity } \\
\text { Test }\end{array}$ & $\begin{array}{l}\text { Homo } \\
\text {-skedastisitas }\end{array}$ & OK & $\begin{array}{l}\text { Obs }^{*} R- \\
\text { squred=21.57589 } \\
\text { Prob=0.7586 }\end{array}$ & \\
\hline $\begin{array}{l}\text { Non } \\
\text { Multikolinearit } \\
\text { as }\end{array}$ & $\begin{array}{l}\text { Corelationantar } \\
\text { regressornya } \\
\text { atau Rj (antar } \\
\text { regressornya) }\end{array}$ & & $\begin{array}{l}\text { Tidak terjadi } \\
\text { mutikolinearitas } \\
\text { yang serius }\end{array}$ & $\begin{array}{l}\text { corelasi max = } \\
0.904546 \text { dan } \\
\text { maksimum Rj yang } \\
\text { didapatkan adalah } \\
0.878731\end{array}$ & $\begin{array}{l}\text { Multikolinearitas } \\
\text { serius terjadi } \\
\text { ketika Rjnya } \\
\text { melebihi } 0.9\end{array}$ \\
\hline
\end{tabular}

Tabel 5. Uji Diagnostik Model GTot

\begin{tabular}{|c|c|c|c|c|c|}
\hline Asumsi & Uji & $\mathrm{Ho}$ & Hasil & Indikator Uji & Keterangan \\
\hline Normalitas & JB test & $\begin{array}{l}\text { Residual } \\
\text { Normal }\end{array}$ & $\mathrm{OK}$ & $\begin{array}{l}\mathrm{JB}=0.746031 \text { Prob } \\
=0,688655\end{array}$ & \\
\hline $\begin{array}{l}\text { Spesifikasi } \\
\text { Model }\end{array}$ & $\begin{array}{l}\text { Ramsey Reset } \\
\text { Test }\end{array}$ & $\begin{array}{l}\text { Spesifikasi } \\
\text { Baik }\end{array}$ & Baik & $\begin{array}{l}\text { F- } \\
\text { statistic }=0.287065 \\
\text { Prob }=0.5965\end{array}$ & \\
\hline $\begin{array}{l}\text { Homo- } \\
\text { skedastisitas }\end{array}$ & $\begin{array}{l}\text { White } \\
\text { Heterokedasticity } \\
\text { Test }\end{array}$ & $\begin{array}{l}\text { Homoskedas } \\
\text { tisitas }\end{array}$ & OK & $\begin{array}{l}\text { Obs*R- } \\
\text { squred }=16.59535 P \\
\text { rob }=0.2784\end{array}$ & \\
\hline $\begin{array}{l}\text { Non } \\
\text { Multikolineari } \\
\text { tas }\end{array}$ & $\begin{array}{l}\text { Corelationantar } \\
\text { regressornya } \\
\text { atau Rj (antar } \\
\text { regressornya) }\end{array}$ & & $\begin{array}{l}\text { Terjadi } \\
\text { mutikolinea } \\
\text { ritas yang } \\
\text { serius }\end{array}$ & $\begin{array}{l}\text { corelasi max }= \\
0.945548 \text { dan } \\
\text { maksimum R2 } \\
\text { yang didapatkan } \\
\text { adalah } 0.921445\end{array}$ & $\begin{array}{l}\text { Multikolinearita } \\
\text { s serius terjadi } \\
\text { ketika Rjnya } \\
\text { melebihi } 0.9\end{array}$ \\
\hline
\end{tabular}


parameter yang didapatkan tidak bisa diinterpretasikan. Hasil uji diagnosis yang dilakukan dapat dilihat dalam Tabel 4, sedangkan uji diagnosis hasil estimasi model dengan menggunakan Gtot dapat dilihat dalam Tabel 5.

Dari hasil uji diagnosis pada Tabel 4 dan 5, model tersebut dapat melewati uji diagnosis. Dari indikator yang ada tidak terdapat pelanggaran terhadap asumsi klasik berkaitan dengan metode yang digunakan.

\section{Koefisien Hasil Estimasi dan Interpretasinya}

Setelah dilakukan uji diagnosis hasil estimasi maka kita interpretasikan hasil estimasi yang didapatkan Dari tabel hasil estimasi sebelumnya maka bisa kita tampilkan lagi secara lebih sederhana hasil estimasi untuk kedua model tersebut yaitu model untuk pengeluaran human capital dan model dengan menggunakan pengeluaran total pemerintah sebagaimana terlihat pada Tabel 6.

Tabel 6. Hasil Estimasi Pengeluaran Pemerintah Menurut Fungsi

\begin{tabular}{l|r|r}
\hline \multicolumn{3}{c}{ Dependent Variabel: $\log (\mathrm{VALUE})$} \\
\hline Variable & $\begin{array}{c}\text { Model Human } \\
\text { Capital } \\
\text { Investment }\end{array}$ & $\begin{array}{c}\text { Model } \\
\text { Pengeluran } \\
\text { Total } \\
\text { Pemerintah }\end{array}$ \\
\hline C & $7.651296^{* * *}$ & $4.562442^{* *}$ \\
GEDUC & $-5.18 \mathrm{E}-07^{* * *}$ & $-5.60 \mathrm{E}-07$ \\
GHEAL & $-52 \mathrm{E}-07^{* * *}$ & $2.69 \mathrm{E}-08$ \\
GFAC & $1.38 \mathrm{E}-08^{* * *}$ & $6.89 \mathrm{E}-09$ \\
Gtot & $-0.33994^{* *}$ & $-0.21774^{*}$ \\
LOG(KLB) & 0.04656 & $0.192002^{* *}$ \\
LOG(POP) & & \\
LOG(LAN & & \\
D) &
\end{tabular}

Catatan: $*, * *, * * *$ menunjukkan signifikan pada level $10 \%, 5 \%$, dan $1 \%$.
Dalam model human capital investment dapat kita lihat bahwa variabel human capital seperti pengeluaran pemerintah dalam bidang pendidikan mempengaruhi perubahan kenaikan produktivitas tenaga kerja. Di mana kenaikan 1 unit pengeluaran pemerintah di bidang pendidikan mengakibatkan menurunnya produktivitas tenaga kerja sebesar $0.00000052 \%$ atau setiap Rp1T kenaikan pengeluaran bidang pendidikan akan menurunkan produktivitas tenaga kerja sebesar $0.52 \%$.

Hal ini bisa terjadi karena pengeluaran pemerintah di bidang pendidikan tidak dilakukan semestinya. Seperti kita ketahui banyaknya pengeluaran pendidikan yang tidak sesuai dengan fungsinya untuk mendorong kualitas pendidikan itu sendiri. Banyak pengeluaran yang dilakukan hanya semata-mata proyek. Banyak juga pengeluaran pendidikan yang dilakukan penggelapan, pemotongan anggaran untuk kepentingan pribadi sehingga pembangunan pendidikan tidak optimal atau kualitasnya sangat buruk. Lebih dari itu, pengeluaran pemerintah yang dijadikan pengeluaran pembangunan di bidang pendidikan dalam arti fisik, banyak fakta menjelaskan bahwa fisik yang dihasilkan tidak berkualitas atau nilainya jauh dari standar atau anggaran yang telah ditentukan. Bukan suatu rahasia lagi bahwa anggaran untuk kesehatan dan pendidikan pada titik akhirnya khususnya untuk pembangunan banyak mengalami pemotongan anggaran bahkan bisa mencapai 40\%-nya saja. Banyak kita lihat selama ini sarana dan prasarana pendidikan yang kualitasnya tidak sebagaimana anggaran yang dikeluarkan sehingga banyak mengalami kerusakan sehingga umur 
pemakaiannya jauh lebih pendek dibandingkan umur ekonomis yang semestinya.

Sedangkan pengeluaran di bidang kesehatan tidak menunjukkan produktivitas terhadap kenaikan produktivitas tenaga kerja. Hal ini ditunjukkan dengan tidak signifikannya variabel tersebut terhadap variabel dependen.

Pengeluaran pemerintah lainnya sesuai dengan bidangnya didapatkan bahwa pengeluaran fasilitas umum dan perumahan mempengaruhi produktivitas tenaga kerja. Di mana setiap 1 unit kenaikan pengeluaran bidang fasilitas umum dan perumahan akan meningkatkan $0.00000085 \%$ PDRB per kapita labor atau setiap Rp1T kenaikan pengeluaran bidang fasilitas umum dan perumahan akan meningkatkan produktivitas tenaga kerja sebesar $0.85 \%$.

Dari hasil tersebut dapat diartikan bahwa pengeluaran pemerintah di bidang human capital oleh pemerintah provinsi tidak menunjukkan kenaikan produktivitasnya malah mengakibat penurunan produktivitas tenaga kerja. Hasil yang positif ditunjukkan dengan adanya produktivitas pengeluaran di bidang fasilitas umum dan perumahan menunjukkan pengaruh yang baik pada kenaikan produktivitas tenaga kerja.

Sedangkan variabel lain menunjukkan bahwa variabel stok kapital perkapita dan populasi mempengaruhi produktivitas tenaga kerja. Sesuai yang diharapkan, peningkatkan investasi bruto masyarakat provinsi produktif meningkatkan produktivitas tenaga kerja sedangkan populasi malah akan menekan produktivitas tenaga kerja. Hal ini menunjukkan bahwa semakin banyak populasi akan menekan pertumbuhan produktivitas tenaga kerja daerah yang bersangkutan. Sedangkan luas tanah yang dimiliki oleh wilayah regional provinsi tidak bepengaruh terhadap produktivitas tenaga kerja meskipun tanda yang dihasilkan sesuai dengan yang diharapkan.

Sedangkan dari estimasi model yang menggunakan Gtot, fakta menunjukkan bahwa pengeluaran pemerintah secara total tidak berpengaruh terhadap produktivitas tenaga kerja. Ini menunjukkan bahwa banyaknya pengeluaran pemerintah yang dilakukan tidak efektif mendorong pertumbuhan ekonomi. Hal ini bisa terjadi karena pengeluaran pemerintah secara total tidak dikeluarkan pada sesuai dengan bidangnya yang mendorong produktivitas ekonomi namun lebih banyak pada belanja pegawai. Untuk diketahui berdasarkan rekap APBD pemda kabupaten dan provinsi 2012, rasio total belanja pegawai terhadap belanja pemerintah rata-rata sejumlah $42 \%$. Ini artinya $42 \%$ dari belanja total dalam APBD dihabiskan untuk menjadi pendapatan pegawainya. Jika dibandingkan dengan pengeluaran pemerintah sesuai bidangnya maka dapat dilihat pengeluaran pemerintah sesuai dengan bidangnya lebih produktif daripada pengeluaran pemerintah secara total. Lebih dari itu, rendahnya kapasitas caleg DPR atau DPRD yang mempunyai akses untuk mencapai posisi itu karena sistem demokrasi yang diterapkan juga turut menyumbang buruknya kualitas pengelolaan keuangan daerah karena rendah kontrol yang bisa dilakukan ketika mereka menjadi anggota dewan.

Sesuai dengan APBD 2012, rasio belanja modal seluruh pemda provinsi dan kab/kota 
se Indonesia sebesar $22 \%$ sedangkan untuk pemprov sendiri sebesar $18 \%$. Padahal dalam realisasinya belanja modal cenderung tidak tercapai atau kurang sedangkan belanja pegawai cenderung melebihi dari anggarannya (Kemenkeu 2013). Dalam Perpres No. 5 Tahun 2010, belanja modal dalam APBD adalah sekurang-kurangnya sebesar 30\% dari APBD.

Dari uraian di atas dapat diterangkan secara singkat bahwa pengeluaran pemerintah dalam rangka investasi human capital tidak produktif meningkatkan PDRBperkapita tenaga kerjanya sebagaimana pengeluaran pemerintah secara total. Jika dilihat secara total sesuai dengan fungsinya, pengeluaran pemerintah bisa meningkatkan produktivitas tenaga kerja dan lebih produktif dibandingkan pengeluaran pemerintah secara total.

Lebih dari itu, negatifnya koefisien yang didapatkan dari human capital bisa didapatkan karena memang human capital sifatnya mempunyai lag atau kelambanan dalam dampaknya atau diperoleh pengaruhnya dalam jangka panjang sehingga memerlukan pendekatan estimasi model dinamis. Sedangkan model yang kita lakukan adalah model statis. Namun tidak bisa dipungkiri estimasi dinamis menghadapi hambatan mengingat keterbatasan data dengan mempertimbangkan data keuangan daerah yang mengalami perubahan standar sejak diterapkannya desentralisasi fiskal tahun 2000-an. Jika data time series diterapkan maka akan banyak data yang terpotong yang pada ujungnya degree of freedom datanya menjadi lebih kecil bahkan tidak mencukupi untuk kepentingan estimasi.

\section{SIMPULAN}

Temuan yang didapatkan dari penelitian ini adalah pengeluaran pemerintah daerah provinsi dalam human capital investment tidak mempengaruhi peningkatan produktivitas tenaga kerja. Hal ini bisa terjadi karena kualitas pengeluaran pemerintah dalam hal ini kurang berkualitas sehingga tidak efektif meningkatkan pertumbuhan riil regional provinsi.

Pengeluaran pemerintah provinsi secara total tidak mempengaruhi peningkatan produktivitas tenaga kerja. Hal ini bisa terjadi karena pengeluaran yang dilakukan banyak dikeluarkan komposisinya untuk belanja pegawai.

Pengeluaran pemerintah dalam human capital invesment sama tidak produktifnya dengan pengeluaran pemerintah secara total. Hal ini bisa terjadi karena pengeluaran yang dilakukan bukan dalam hal meningkatkan produktivitas faktor total sehingga tidak meningkatkan koefisien teknologi daerah yang bersangkutan sebagaimana halnya unit produksi.

Meskipun dalam human capital invesment, pengeluaran pemerintah tidak meningkatkan produktivitas tenaga kerja namun berdasarkan pengeluaran menurut bidang/fungsinya, pengeluaran pemerintah dalam bidang fasilitas umum dan perumahan mempengaruhi secara positif produktivitas tenaga kerja. Ini sekaligus juga menunjukkan bahwa infrastruktur berupa fasilitas umum penting sekali untuk mendorong peningkatan produktivitas tenaga kerja.

Beberapa rekomendasi yang dapat diajukan adalah diperlukan monitoring yang kuat dalam pelaksanaan pengeluaran pemerintah dalam human capital investment 
agar pengeluaran yang dilakukan benarbenar dilakukan secara berkualitas sehingga pengeluaran yang dilakukan meningkatkan total factor productifity dari regional yang bersangkutan.Prinsip-prinsip pengelolaan keuangan daerah harus dilakukan seperti halnya tertib, taat pada aturan, efekti dan efisien, ekonomis, transparan, bertanggungjawab, berkeadilan, kepatutan, dan manfaat pada masyarakat (Permendagri No. 13 Tahun 2006). Di mana, dalam pelaksanaannya, belanja daerah harus mengikuti prinsip hemat, tidak mewah, efisien, dan sesuai dengan kebutuhan teknis yang disyaratkan; efektif, terarah dan terkendali sesuai dengan rencana, program/kegiatan, sesuai fungsi setiap departemen/lembaga/pemerintah daerah; dan mengutamakan penggunaan produksi dalam negeri (Keppres No.42 Tahun 2002).

Pengeluaran pemerintah sebaiknya lebih difokuskan dengan meningkatkan belanja modal mengingat komposisi belanja pegawai yang cukup besar dalam total belanja pemerintah regional provinsi, minimal 30\% sesuai aturan yang ada. Diperlukan efisiensi belanja pegawai dengan berusaha merampingkan size pemerintah yang ada namun memperhatikan kinerja pegawainya dengan reward yang memberikan kompensasi yang layak bagi pegawai pemda provinsi. Pengeluaran dalam hal fasilitas umum dan pengeluaran dalam kaitannya dengan perumahan perlu ditingkatkan mengingat terbukti berpengaruh posistif dalam meningkatkan pertumbuhan produktivitas tenaga kerja regionalnya. Hal ini terjadi mengingat fasilitas umum dan perumahan adalah komponen yang produktif dalam meningkatkan perekonomian regional.

Untuk memastikan pelaksanaan pengelolaan keuangan daerah yang baik banyak hal yang bisa diterapkan. Suryanto (2014) mengajukan hal-hal yang bisa diterapkan antara lain kontrol DPRD, akuntabilitas legal, desentralisasi dan partisipasi, kontrol adminitrasi internal, serta optimalisasi peran media dan opini publik.

Diperlukan proxy dari variabel stok modal yang ada sehingga bisa mendapatkan hasil estimasi yang sesuai dengan yang diharapkan. Untuk lebih mendapatkan hasil estimasi yang sesuai maka dalam penelitian yang selanjutnya sebaiknya dilakukan estimasi dengan data time series mengingat pengaruh human capital invesment memberikan pengaruh dalam jangka panjang. Untuk itu juga diperlukan estimasi time series dengan model dinamis mengingat diperlukannya lag dalam melihat pengaruh human capital invesment dalam produktivitas tenaga kerja.

\section{DAFTAR PUSTAKA}

Agrawal, A. \& Ribot, J. (2002). Analyzing Decentralization: A Frame Work with South Asian and East African Environmental Cases. Working Paper Series. Institutions and Governance Program World Resources Institute. Washington. D.C. 20002.

Bardhan, P. \& DilipMookherjee (2005). Decentralization. Corruption and Government Accountability: An Overview. For 'Handbook of Economic Corruption' edited by Susan RoseAckerman. Edward Elgar. Revised. June 202005. 
Dao, M.Q. (2012). Government Expenditure and Growth in Developing Countries. Progress in Development Studies 12(1), 77-82.

Denaux, Z.S. (2007). Endogenous Growth. Taxes and Government Spending: Theory and Evidence. Review of Development Economics. 11(1), 124-138.

Gupta, S., et.al. (2002). Fiscal Dimensions of Sustainable Development. Prepared for World Summit on Sustainable Development Johannesburg. August 26September 4. 2002. Washington. D.C.: International Monetary Fund. Fiscal Affairs Dept. 2002.

Kaufman, Daniel, AartKraay, \& Mastruzzi, M. (2006). Governance Matters V: Aggregate and Individual Governance Indicators for 1996-2005. The World Bank. September 2006.

Kemenkeu (2012). Nota Keuangan Dan Rancangan Anggaran Pendapatan Dan Belanja Negara Tahun Anggaran 2013 Republik Indonesia. Kemenkeu RI.

Kemenkeu (2012). Ringkasan APBD Pemda seluruh Indonesia. Kemenkeu. Dirjen Perimbangan Keuangan Daerah.

Kemenkeu (2013). Evaluasi Belanja Modal Daerah. Dirjen Perimbangan Keuangan Daerah Kemenkeu RI 2013.

Kyriacou, A.P. \& Roca-Sagalés, O. (2008). Fiskal Decentralization and The Quality of Government: Evidence from Panel Data. Universitat Autònoma de Barcelona: Instituto de Estudios Fiskales.

La Porta, R., Lopes-de-Silanez, F., Shleifer, A., \& Vishny, R. (1998). The Quality of
Government. NBER Working Paper No.6727. September 1998.

Lyakurwa, W.M. (2007). Human Capital and Technology for Development: Lessons for Africa. ADB Annual Meetings Symposium. Shanghai. China14-17 May 2007.

Oluwatobi, S.O., \& Ogunrinola, O.I. (2011). Government Expenditure on Human Capital Development: Implications for Economic Growth in Nigeria. Journal of Sustainable Development. 4,(3), 72-80.

Stansel, D. (2009). Local Government Investment and Long-Run Economic Growth. The Journal of Social. Political. and Economic Studies, 34(2), 244.

Suprayitno, B. (2011). Desentralisasi Fiskal Dan Korupsi: Fakta Dalam Otonomi Daerah Di Indonesia. Thesis. UGM tidak dipublikasikan.

Suryanto (2014). Menyoal Desentralisasi Fiskal: Mempertanyakan Akuntabilitas Keuangan Pemerintahan Daerah. Diakses dari http://www.stialan.ac.id 19 Agustus 2014:6.59.

Treisman (2002). Decentralization and the Quality of Government. Department of Political Science. University of California. Los Angeles. October. 2002.

UNDP (2010). Peningkatan Kinerja Pembangunan Daerah: Alat-alat Praktis dari Indonesia. BAPPENAS dan UNDP. Indonesia April 2010.

Yeoh, M. \& Stansel, D. (2013). Is Public Expenditure Productive? Evidence from the Manufacturing Sector in U.S. Cities. 1880-1920. Cato Journal. 33(1). 